ARTICLE HISTORY: Received: August: 6, 2021 Accepted: September 27, 2021 Published: October 4, 2021

УДК: 336.74

ПРОБЛЕМЫ РЕГУЛИРОВАНИЯ РЫНКА КРИПТОВАЛЮТ В РОССИИ И МИРЕ

Панкрухина А.М.

студентка 3 курса Факультета экономики и бизнеса

Морозко Н.И.

д.э.н., профессор

Департамента банковского дела и финансовых рынков

Финансовый университет при Правительстве Российской Федераџии,

2. Москва, Россия

\title{
PROBLEMS OF REGULATION OF THE CRYPTOCURRENCY MARKET IN RUSSIA AND THE WORLD
}

\author{
Pankrukhina A.M. \\ 3rd year student of the Faculty of Economics and Business \\ Scientific supervisor: Morozko N.I., \\ Doctor of Economics, Professor of the Department of Banking and Financial Markets \\ Financial University under the Government of the Russian Federation, Moscow, Russia
}

\begin{abstract}
Аннотация. Появление криптовалюты стало громким событием, вокруг которого до сих пор не утихают споры. Некоторые видят в ней прямую угрозу безопасности национальной экономики, некоторые долгожданное торжество рыночных принципов саморегуляции. Необходимость, целесообразность и наиболее результативная модель регулирования рынка криптовалюты являются животрепещущими вопросами. Их актуальность в контексте российской реальности доказывает хотя бы тот факт, что Россия является одной из стран-лидеров по использованию цифровой валюты, а количество криптокошельков, открытых россиянами превышает 8 млн. Исследовать существующие на данный момент мнения и накопленный опыт решения проблемы регулирования рынка цифровой валюты и является целью данной статьи.

Abstract. The appearance of cryptocurrency has become a high-profile event, around which disputes still persist. Some see it as a direct threat to the security of national economy, some as a long-awaited triumph of market principles of self-regulation. The necessity, expediency and the most effective model of regulating the cryptocurrency market are burning issues. The relevance of these issues in the context of Russian reality is proved at least by the fact that Russia is one of the leading countries in the use of digital currency, and the number of crypto wallets opened by Russians has exceeded 8 million. The aim of this article is to review the currently existing opinions and accumulated experience in solving the problem of regulating the digital currency market.
\end{abstract}

Ключевые слова: криптовалюта, цифровые активы, виртуальная валюта, цифровая валюта, регулирование криптовалют

Keywords: cryptocurrency, digital assets, virtual currency, digital currency, cryptocurrency regulation

Появление криптовалюты связано с именем Сатоши Накамото, человека или группы людей, которыми в 2009 году был создан биткоин - первая криптовалюта. В основе криптовалюты лежит технология блокчейн. Она посредством шифрования обеспечивают прямой обмен ценностями между сторонами без вмешательства банков, правительств и других посредников [4]. Данная характеристика криптовалют является ее качественным преимуществом перед электронными деньгами. Например, для осуществления транзакции с использование банковской карты, ее владельцу необходимо подтверждение банка о наличии на счете определенной суммы денег и возможности их списания. В случае криптовалюты подтвердить транзакцию может любой участник рынка. Таким образом, принцип децентрализации, лежащий в основе крипловалюты, позволяет нивелировать риски, связанные со сбоями в функционировании какого-либо центра, от исправности работы которого зависят все участники системы.

Необходимость регулирования рынка криптовалюты объясняется рисками, присущими процессу её обращения и использования. Во-первых, у криптовалюты отсутствует единый эмитент, выпустить новую форму виртуальной валюты, согласно принципу децентрализации, может любой участник системы, при этом сохранив свою анонимность. Из этого следует, что невозможно идентифицировать субъекта экономических отношений, который гарантировал бы наличие имущественного обеспечения, эмитируемого им платежного средства для удовлетворения претензий со стороны пользователя данной криптовалюты. 
Отсюда вытекает второй риск - невозможность защиты прав потребителей цифровой валюты, как пользователей финансовых услуг вследствие того, что большинство сделок совершается в Интернетпространстве и не попадает ни под какое законодательное регулирование. То есть привлечь эмитента к ответственности за неисполнение им своих обязательств не представляется возможным.

В-третьих, анонимность гарантирована участниками рынка криптовалюты не только в случае эмиссии ими новых криптовалют, но и в случае совершения транзакций с уже существующими. Более, того при приобретении цифровой валюты и обмене ею не предусмотрен контроль источников получения средств, на которые данная сумма криптовалюты была приобретена, что создает прямой риск использования рынка криптовалют как места для легализации преступных доходов и финансирования терроризма. Так, по данным Банка России криптовалюта активно используется в преступном сообществе для сокрытия денежных транзакций [2]. Кроме того, есть прецеденты использования цифровой валюты в мошеннических целях, а анонимность, гарантированная как получателю, так и отправителю средств, позволяет виновной стороне избежать наказания за свою преступную деятельность.

В-четвертых, рынок криптовалют является международным, что позволяют его участникам, выводить средства, заработанные в одном государстве в юрисдикцию другого без декларации истинной величины своего дохода, тем самым уклоняясь от уплаты налогов. Данное явление, именуемое оттоков капитала, приводит к тому, что денежных средства, заработанные с использованием ресурсов, как материальных, так и человеческих, одного государства могли бы быть реинвестированы в эту же экономику и послужить развитию ее потенциала, модернизации производства и созданию новый рабочих мест. Вместо этого они оседают в других странах и служат их развитию. Более того, налоги, уплаченные с реальных доходов, были бы использованы на создание общественных благ, инфраструктуры и поддержание экономической безопасности деятельности, в том числе субъекта, честно заплатившего налоги.

В-пятых, курсы криптовалют крайне чувствительны к заявлениям представителей крупного бизнеса, публикациям новых требований национальными регуляторами, новостям о проблемах в работе криптовалютных бирж и т. п. То есть криптовалюта обладает высокой волатильностью, что повышает риски финансовых потерь у всех участников рынка. Так, своим влиянием на стоимость криптовалют известен американский предприниматель Илон Макс. К примеру, в мае 2021 года после его заявления о том, что Tesla планирует перестать принимать биткоины в качестве оплаты при покупке электромобилей по причине негативного влияния добычи криптовалюты на экологию, курс биткоина снизился на $15 \%$ [8].

Стоит отметить, что сервисы по обмену криптовалютой не раз были свидетелями сознательных манипуляций рынком при помощи ботов, что приводило к резкому снижению и роста стоимости криптовалют с вытекающими негативными последствиями. На традиционных фондовых биржах данная проблема решается путем мониторинга и установления «правил игры» со стороны единого регулятора. Однако, регулирования криптовалютных бирж на данный момент либо отсутствует, либо существует в виде запрета на их существование. Так, например, Центральный банк Китая заявил, что все операции с криптовалютой, включая услуги иностранных бирж, будут считаться незаконной финансовой деятельностью. После данного заявления курс биткоина снизился на 6\% [11].

Данному заявлению предшествовала публикация уведомления, в котором биткоин определялся как виртуальный товар, не имеющий юридического статуса, эквивалентного валюте. Важно отметить, что такое резко негативное отношение властей Китая к криптовалюте многие эксперты связывают с активными разработками в области цифровой национальной валюты - цифрового юаня. Так, в Народном банке Китая еще в 2016 году отметили возможный положительный эффект от внедрений расчетов в цифровой валюте, в частности сокращение эксплуатационных расходов. Однако, существенным недостатком классических криптовалют является их анонимность, которая не позволит регулятору контролировать транзакций граждан Китая. Решить эту проблему и в добавок сделать повседневные расчеты более удобными призван цифровой юаня, тестирование которого проводятся в Китае с апреля 2020 года [9].

Схожими причинами негативно относиться к криптовалюте обладает Центробанк России, который также готовится в 2022 году начать тестирования национальной цифровой валюты - цифрового рубля. Еще в 2017 году, когда национальные регуляторы только начинали формировать свое отношение к криптовалюте и необходимости ее регулирования, председатель Банка России Эльвира Набиуллина заявила о том, что мегарегулятор против частных цифровых денег [7]. В октябре 2020 года в Докладе для общественных консультаций «Цифровой рубль» Банк России открыто заявил о том, что криптовалюта не может быть в признана деньгами в силу того, что ею не выполняются функции, обязательные для «товара», играющего при обмене роль денег. Однако, цифровой рубль, который будет эмитироваться Центробанком, будет устойчивой, ориентированной на безопасность потребителей, созданной в соответствии с запросами граждан и бизнеса, полноценной третьей формой денег наравне с наличным и безналичным рублем [3].

Повсеместного внедрения цифрового рубля станет важным событием через несколько лет. Но совсем недавно произошло другое долгожданное событие российского правового поля в части регулирования рынка криптовалют - принятие Федерального закона № 259-Ф3 «О цифровых 
финансовых активах» (далее - Закона). Законопроект рассматривался 2,5 года и многие представители криптобизнеса возлагали на него большие надежды. В частности, ожидалось, что на место разрозненных трактовок придет единый понятийный аппарат, который послужит основой для создания в России полноценного правового поля в области криптовалютного регулирования [12]. В итоге ожидания оправдались лишь частично.

Так, с 1 января 2021 года в России легализован криптовалютный рынок и законодательно закреплено понятие криптовалюты. Стоит отметить, что само понятие «криптовалюта» в Законе не упоминается. Объектов регулирования Ф3 №259 является «цифровая валюта», под которой, по словам Анатолия Аксакова, понимается именно криптовалюта [5]. В любом случае, под цифровой валютой следует понимать некоторый объем электронных данных, выполняющих роль средства платежа, но не являющихся официальной денежной или расчетной единицей, либо выполняющих роль инвестиций. И в первом, и во втором случае невозможно определить лицо, ответственное за эмиссию таких электронных данных [1].

Однако, данное определение достаточно размытое и противоречит ряду норм этого же нормативноправового акта. Например, ст. 14 все того же ФЗ о ЦФА говорит о том, что цифровая валюта на территории РФ не может являться встречным предоставлением в обмен на товары и услуги, что противоречит определению цифровой валюты как средства платежа. Еще более непонятным данное положение становится в контексте поправок, внесенных в ряд других законодательных актов, признающих криптовалюту в качестве имущества [5].

Кроме того, согласно Закону рассчитывать на судебную защиту прав на криптовалюту смогут только те собственники цифровой валюты, которые задекларировали ее должным образом и заплатили налоги на доход от нее. Данный пункт Федерального закона также вызвал некоторые недопонимание, так как некоторые собственники криптовалюты не получаю доход от операций с ней, а используют виртуальную валюту как способ накопления или сохранения сбережений.

Более того, в Законе не решены многие насущные вопросы. В частности, вопрос налогообложения дохода от операций с криптовалютой. Хотя некоторые специалисты утверждают, что заниматься выработкой регуляторных мер по вопросу налогообложения на данной стадии развития рынка преждевременно по двум причинам. Во-первых, до сих пор не установлены правила оборота криптовалюты, что делает бессмысленными обсуждения налогового режима для дохода от этого оборота. Во-вторых, с учетом имеющегося законодательства не понятно, как считать прибыль от сделок с криптовалютами и что будет являться налогооблагаемой базой.

Однако, Закон о ЦФА в нынешней редакции уже делает достаточно для того, чтобы иметь и развивать криптобизнес на территории РФ было невыгодно, именно так считают большинство экспертов [12]. «Масло в огонь» подливают поправки, которые могли бы войти в существующую версию ФЗ о ЦФА, но не вошли благодаря резкой критики со стороны общественности. Речь идет о запрете майнерам получать оплату в виде криптовалюты, что является общепринятой практикой по всему миру. За нарушение данного запрета законодатели предполагали привлекать к административной и уголовной ответственности в виде штрафа до 100 тыс. руб и лишения свободы до 7 лет, если нарушителем является физическое лицо. В случае с юридическими лицами предлагалось установить штраф в размере 1 млн руб [10].

Однако, важно упомянуть, что не существует «точки невозврата» для законодательных органов в вопросе регулирования рынка криптовалюты. Иными словами, если вначале регулятор демонстрирует негативное отношение к цифровой валюте, то это не означает, что денежные власти не могут изменить вектор регулирования и начать поддерживать криптобизнес, брать на себя риски, связанные с высокой волатильностью цифровой валюты и недобросовестностью некоторых участников рынка. Более того, законодатели могут использовать инструмент нормотворчества с целью повышения безопасности, а следовательно привлекательности использования криптовалюты.

Отличным примером смены направления регулирования криптовалютного рынка является опыт Резервного банка Индии. Так, еще в 2018 году криптовалюта в Индии считалась незаконным использовать цифровую валюту как средство платежа. Запрет распространялся не только на операции с криптовалютой, но и на конвертацию национальной валюты в цифровую. Но в 2019 году запрет был снят, и началась интеграция финансового инструмента xCurrent 4.0. По сегодняшний день любой желающий может стать пользователем сети Ripple и осуществлять на ее базе мгновенные транзакции [4].

Некоторые страны не проходили этап «запрещающего» регулирования, а изначально избрали другой вектор. Так, например, Центральный банк Финляндии заявил о бессмысленности регулирования рынка криптовалюты. Причиной такого отношения является децентрализация и абсолютная транспарентность обмена цифровой валютой, который выстроен на открытом протоколе и поддерживается разработчиками со всего мира [4].

В случае, если позиция финского регулятора кажется чересчур рискованной, можно рассмотреть модель США. Так, американские денежные власти проявляют живой интерес к вопросу регулирования рынка виртуальной валюты - к 2020 году Конгресс США представил 32 законопроекта касательно криптовалюты. Однако, большинство из них призваны лишь минимизировать риски легализации доходов от преступной деятельности при помощи сделок с виртуальной валютой [6]. В остальном 
американские парламентарии полагаются на принцип децентрализации и невидимую руку криптовалютного рынка.

В заключении, основными проблемами регулирования рынка криптовалют являются:

1. новизна, малоизученность криптовалюты как явления и недостаточность накопленного опыта для формирования полноценного и комплексного подхода к регулированию;

2. принцип его децентрализации, лежащий в основе криптовалютного рынка и предполагающий отсутствие регулирования;

3. недопонимание государственными структурами запросов и потребностей бизнеса, что приводит к выработке законодательных мер, идущими в разрез интересам общества;

4. интернациональность рынка криптовалют, из-за чего добиться успехов в его регулировании можно лишь путем сотрудничества разных стран, которые пока сконцентрированы на выработке внутренних норм, а не на кооперации с мировым сообществом.

\section{Список использованных источников}

[1] Федеральный закон от 31 июля 2020 г. N 259-Ф3 "О цифровых финансовых активах, цифровой валюте и о внесении изменений в отдельные законодательные акты Российской Федерации" 2017)

[2] Обзор по криптовалютам, ICO (initial coin offering) и подходам к их регулированию (декабрь,

[3] Доклад для общественных консультаций «Цифровой рубль» (октябрь, 2020)

[4] Бондарев М. С. Регулирование криптовалютного рынка: проблемы, мировая практика / М. С. Бондарев // Вестник Евразийской науки - 2020 - №2

[5] Криптовалюта в России: законодательное недорегулирование - Режим доступа: https://www.garant.ru/news/1448450/ (дата обращения 26.09.2021)

[14] Congress Has Now Introduced 32 Crypto And Blockchain Bills - Режим доступа: https://www.forbes.com/sites/jasonbrett/2020/04/28/congress-has-introduced-32-crypto-and-blockchain-billsfor-consideration-in-2019-2020/?sh=2395d8881d61 (дата обращения 26.09.2021)

[7] Банк России вновь выступил против использования криптовалют внутри страны - Режим доступа: https:/www.rbc.ru/crypto/news/60c86dd29a7947fced2cf180 (дата обращения 26.09.2021)

[8] Как Илон Маск манипулирует рынком криптовалют и зачем он это делает - Режим доступа: https://www.forbes.ru/tehnologii/435705-kak-ilon-mask-manipuliruet-rynkom-kriptovalyut-i-zachem-eto-delaet (дата обращения 26.09.2021)

[9] Контроль за населением и независимость от доллара: зачем Китай создает свою цифровую валюту - Режим доступа: https://www.forbes.ru/finansy-i-investicii/426079-kontrol-za-naseleniem-inezavisimost-ot-dollara-zachem-kitay-sozdaet (дата обращения 26.09.2021)

[51] Минфин предложил ввести запрет на сделки с криптовалютой - Режим доступа: https://www.rbc.ru/crypto/news/5f5092f19a79475b836fe868 (дата обращения 26.09.2021)

[11] Центробанк Китая объявил операции с криптовалютами вне закона - Режим доступа: https://www.forbes.ru/finansy/441015-centrobank-kitaa-ob-avil-operacii-s-kriptovalutami-vne-zakona (дата обращения 26.09.2021)

[12] Что не так с законом «О ЦФА». Все про регулирование криптовалют в России - Режим доступа: https://www.rbc.ru/crypto/news/5f69eab99a794753755fe0b9 (дата обращения 26.09.2021)

\section{References.}

[1] Federal law of July 31, 2020 No. 259-FZ "On digital financial assets digital currency and on amendments to certain legislative acts of the Russian Federation" (in Russian)

[2] a Review on cryptocurrency, ICO (initial coin offering) and approaches to their regulation (December, 2017) (in Russian)

[3] a Report for public consultation "Digital ruble" (October, 2020) (in Russian)

[4] Bondarev, M. S. Regulation of the cryptocurrency market: the problem of world practice / M. S. Bondarev // Vestnik Evroziyskoyi nauki - 2020 - No. 2 (in Russian)

[5] Cryptocurrency in Russia: legislative under-regulation - Access mode: https://www.garant.ru/news/1448450 / (accessed 26.09.2021) (in Russian)

[14] Congress Has Now Introduced 32 Crypto And Blockchain Bills - Access Mode: https://www.forbes.com/sites/jasonbrett/2020/04/28/congress-has-introduced-32-crypto-and-blockchain-billsfor-consideration-in-2019-2020/?sh=2395d8881d61 (accessed 26.09.2021)

[7] The Bank of Russia again opposed the use of cryptocurrencies within the country - Access mode: https://www.rbc.ru/crypto/news/60c86dd29a7947fced2cf180 (accessed 26.09.2021) (in Russian)

[8] How Elon Musk manipulates the cryptocurrency market and why he does it - Access mode: https://www.forbes.ru/tehnologii/435705-kak-ilon-mask-manipuliruet-rynkom-kriptovalyut-i-zachem-eto-delaet (accessed 26.09.2021) (in Russian)

[9] Population control and independence from the dollar: why China is creating its own digital currency Access mode: https://www.forbes.ru/finansy-i-investicii/426079-kontrol-za-naseleniem-i-nezavisimost-otdollara-zachem-kitay-sozdaet (accessed 26.09.2021) (in Russian) 
[51] The Ministry of Finance proposed to introduce a ban on transactions with cryptocurrency - Access mode: https://www.rbc.ru/crypto/news/5f5092f19a79475b836fe868 (accessed 26.09.2021) (in Russian)

[11] The Central Bank of China has outlawed operations with cryptocurrencies - Access mode: https://www.forbes.ru/finansy/441015-centrobank-kitaa-ob-avil-operacii-s-kriptovalutami-vne-zakona (accessed 26.09.2021) (in Russian)

[12] What is wrong with the law "ON CFA". All about the regulation of cryptocurrencies in Russia - Access mode: https://www.rbc.ru/crypto/news/5f69eab99a794753755fe0b9 (accessed 26.09.2021) (in Russian) 
